\title{
«Hun er ikke så flink til å dele». En alternativ tilnærming til sosiale normer om deling i barnehagen
}

\author{
Karianne Franck ${ }^{\star}$ \\ Dronning Mauds Minne Hogskole
}

\begin{abstract}
Sammendrag
At barn skal lære å dele med hverandre, er en del av barnehagens hverdag. Hva som menes med deling og hvordan sosiale normer om deling finner sted i barnehagen, risikerer derimot å bli tatt for gitt i hverdagen. Som forsker opplevde jeg å bli meget forvirret over barnehagens regler og praksiser for deling. Det fremstod som en myriade av regler og normer om når å dele og ikke dele - alt fra å dele en leke sammen til førstemann-sin-rett eller turtaking. I artikkelen gransker jeg derfor nærmere hvordan ulike sosiale normer for deling utspiller seg i barnehagehverdager, og jeg retter et særskilt fokus mot det materielle sin rolle i ulike situasjoner. På bakgrunn av observasjoner og intervju i fire barnehageavdelinger analyseres konkrete hendelser ved bruk av aktør-nettverksteori (ANT). I tråd med ANT anerkjennes det ikke-menneskelige og menneskelige som aktører (jfr. Latour, 2005). Hensikten til artikkelen er å introdusere en alternativ tilnærming til utforskning av hvordan sosiale normer om deling utspiller seg i hverdagslige situasjoner, og å forstyrre etablerte sannheter omkring et tilsynelatende enkelt og uproblematisert område i barnehagers praksis.
\end{abstract}

Nøkkelord: Aktør-nettverksteori (ANT); lekgjenstander; barn; sosial samhandling

\begin{abstract}
Learning to share is a part of children's everyday life in Norwegian early childhood, education and care (ECEC) institutions. However, what it means to share, and the way social norms for sharing take place in ECEC institutions, run the risk of being taken for granted. As a researcher I experienced confusion regarding ECEC institution's rules and practices for sharing. There appeared to be a myriad of rules and norms on when to share and when not to share - varying from sharing a toy together, to the first child's right to ownership, to (children) taking turns. In this article I therefore examine how different social norms for sharing take place in everyday life of ECEC institutions, with particular attention to the role of the material in various situations. Based on observations and interviews in four ECEC units, specific incidences are analyzed using actor-network theory (ANT). In line with ANT, the non-human and human are both recognized as actors (cf. Latour, 2005). The article's objective is to introduce an alternative approach for exploring the manner in which social norms of sharing take place in everyday
\end{abstract}

^Korrespondanse: Karianne Franck, Thrond Nergaardsv. 7, 7044 Trondheim. E-post: Kfr@dmmh.no

(C) 2018 Karianne Franck. This is an Open Access article distributed under the terms of the Creative Commons Attribution 4.0 International License (http://creativecommons.org/licenses/by/4.0/), allowing third parties to copy and redistribute the material in any medium or format and to remix, transform, and build upon the material for any purpose, even commercially, provided the original work is properly cited and states its license.

Citation: Karianne Franck. "Hun er ikke så flink til à dele» En alternativ forståelse av barnehageansattes iverksetting av sosial normer og regler om deling, Vol. 4, 2018, pp. 104-118. http://dx.doi.org/10.23865/ntpk.v4.958 
situations and disturb established truths about a seemingly simple and unproblematized area within ECEC institutions' practices.

Keywords: Actor-network theory (ANT); toys; children; social interaction

Mottatt: August, 2017; Antatt: Mars, 2018; Publisert: Juni, 2018

Deling av leker mellom barn er hverdagslige hendelser i en barnehage. Det samme er episoder der barnehageansatte bryter inn i barns samhandling og sier til barn at de må dele eller vente på tur. På én side fremstår deling som et forholdsvis enkelt prinsipp som barn skal lære fra tidlig alder. I denne artikkelen utfordres derimot en tattfor-gitt forståelse av barnehagens sosiale normer om deling ved å granske nærmere ulike situasjoner i barnehagehverdagen. Artikkelen utforsker spørsmålene: Hvordan utspiller sosiale normer for deling seg i barnehagen, og hvordan bidrar det materielle som aktør? Fokuset for artikkelen vokste fram da jeg som forsker opplevde forvirring i møte med barnehagens tilsynelatende enkle regler for deling. Under observasjon av hverdagen i fire barnehageavdelinger opplevde jeg rett og slett ikke å få grep om de sosiale normene for deling. Det fremstod som en myriade av regler og normer om å dele, og ikke dele, i ulike situasjoner. Det var alt fra normer om felleslek med samme ting (dele leken sammen), førstemann-sin-rett, til turtaking. På samme tid opplevde jeg at det var klare forventninger om at selv de yngste barna skulle forholde seg til denne mengden av regler og normer, til tross for at det til stadighet oppstod situasjoner hvor barn ikke fulgte reglene og normene, og noen barn endte med å bli karakterisert som 'ikke flinke til å dele'.

Denne artikkelen illustrerer og går i dybden på noen av hendelsene hvor jeg observerte sosiale normer for deling utspille seg i møter mellom barnehageansatte, barn og ulike lekgjenstander. Bruk av Latour (2005) og aktør-nettverksteori (ANT) presenterer en alternativ tilnærming og et annerledes blikk på hverdagslige praksiser omkring barns deling i barnehagen. Noe av det som karakteriserer ANT som teoretisk og analytisk tilnærming, er måten både mennesker og ikke-mennesker anses som mulige aktive aktører i skapelse av sosiale fenomen.

Empirien i artikkelen er produsert under feltarbeid i fire barnehageavdelinger, der jeg tilbragte tre uker som deltagende-observatør i hver av avdelingene. I tillegg suppleres observasjonsdataene med utdrag fra intervju med barnehageansatte i de respektive avdelingene. Empirien i artikkelen er ment å illustrere velkjente og hverdagslige hendelser i norske barnehager. I analysen presenteres to situasjoner der det materielle er i særskilt fokus. Deretter beskrives de ansattes egne forklaringer på hvorfor ulike sosiale normer for deling finner sted, for til slutt å rette fokus mot situasjoner med tilsynelatende faste normer for deling. Barna som aktive aktører blir i liten grad fremhevet i artikkelen. Dette er grunnet datamaterialet og analysens fokus, ikke på bakgrunn av barns manglende bidrag $\mathrm{i}$ å forme barnehagens sosiale normer. Hensikten med artikkelen er å introdusere en alternativ tilnærming til utforskning av hvordan sosiale normer om deling utspiller seg i hverdagslige situasjoner og 


\section{Karianne Franck}

forstyrre etablerte sannheter omkring et tilsynelatende enkelt og uproblematisert område i barnehagers praksis.

Jeg har valgt å si at artikkelen tilbyr en alternativ tilnærming, ettersom det meste av tidligere forskning på temaet barns deling har hatt en mer pedagogisk og psykologisk tilnærming. Her har fokus vært på barnets egenskaper og evne til å dele knyttet til barnets sjelsliv, empati, prososiale atferd og barns evne til å ta andres perspektiv (jfr. Alvestad, 2012; Brownell, Svetlova, \& Nichols, 2009; Harris, 1970). En forståelse av deling som en sosial kompetanse eller evne hos enkeltbarn gjenspeiles i kartleggingsskjemaer og praksiser som brukes for å evaluere enkeltbarn i norske barnehager (se for eksempel Ages and Stages Questionnaire og Alle Med). Ved bruk av ANT retter denne artikkelen oppmerksomheten vekk fra deling som en kompetanse eller egenskap lokalisert i barnet, og over til et fokus på hvordan normer for deling utspiller seg på bakgrunn av relasjoner mellom barn, lekgjenstander og barnehageansatte. Artikkelen kan således også leses som et bidrag inn i diskusjoner omkring vurdering og kartlegging av barns egenskaper og kompetanse.

\section{Teoretisk forankring}

Med 'sosiale normer om deling' menes her godt kjente forventninger om hva som anses for å være god sosial samhandling mellom barn i barnehagen. I undersøkelse av barnehageansattes bekymring for at barn kan ha særskilte behov, ble jeg oppmerksom på hvordan barnehagebarn forventes å være sosiale på en viss måte, som i mange situasjoner innebærer å dele leker og sted (Franck, 2014). I denne artikkelen er hensikten å granske nærmere noen av de situasjonene hvor slike forventninger faktisk kommer til syne.

Det teoretiske rammeverket tar utgangspunkt i aktør-nettverksteori (ANT) (Latour, 2005). I møte med barnehagens normer for deling ble jeg tidlig nysgjerrig på hvordan lekgjenstandene utgjorde en forskjell når de sosiale normene om deling utspilte seg. I forsøk på å granske det materielle sin rolle opplevde jeg at de teoretiske rammeverkene jeg var vant til å bruke (f.eks. sosiale konstruksjoner, diskurs, Foucault) la lite vekt på hvordan det sosiale er sammenvevd med materialer og ting. I studier av det sosiale er det i stor grad språk og mennesker som står i sentrum for analyse, hvorpå det materielle enten ble skjøvet til sidelinjen eller redusert til objekt som det sosiale virket $p a ̊$. For å rette fokus mot det materielle sitt bidrag valgte jeg derfor å se til ANT der relasjonene og samspillet mellom det menneskelige og det materielle fremheves, uten å gi det ene forrang over det andre (Latour, 2005). Til tross for dette kan ANT sies å ha mye til felles med andre sosiologiske tilnærminger som fokuserer på det sosiale livets relasjonelle, konstruerte og prosessuelle karakter (Prout, 2005). På samme tid som ANT skiller seg fra andre teorier ved å ha et gjennomgående sterkt fokus på det materielle, og det sosiale som bestående av forbindelser mellom menneskelige og ikke-menneskelige entiteter. Studier av det sosiale kan sies å ha utallige ulike måter å definere og beskrive begrepet 'sosial', men forenklet kan man si at det er blitt brukt for primært å refere til en form for menneskelig 
virkelighet adskilt fra 'natur' og det materielle (Dolwick, 2009). Dette har ført til at studier av det sosiale har vært kritisert for å ignorere det materielle sin innvirkning, eller rettere sagt "...move too quickly to a non-material version of the social» (Law, 2009, s. 148).

I ANT fremheves en forståelse av det sosiale som forbindelser (associations), og dette inkluderer alt som kan forbindes: både menneskelig og ikke-menneskelig (Dolwick, 2009). Utgangspunktet i ANT er at det sosiale ikke kategorisk kan skilles vekk fra den materielle virkeligheten. Som påpekt av Latour: «There exists no relation whatsoever between 'the material' and 'the social world', because it is this very division which is a complete artifact» (Latour, 2005, s. 75-76). Det sosiale og det materielle tilnærmes dermed ikke som separate domener, men sammenvevde $\mathrm{i}$ form av forbindelser mellom menneskelige og ikke-menneskelige aktører.

ANT og Latour kan nok sies å ha vært mer opptatt av det ikke-menneskelige som aktør enn å undersøke det menneskelige, som for eksempel moral (Krarup and Blok, 2011). Så på én side er det utfordrende å bruke ANT som rammeverk i en utforskning av sosiale normer. På samme tid er det nettopp vektleggingen av det ikke-materielle innen ANT jeg fant nyttig for å få fram nye refleksjoner og beskrivelser av hverdagslige situasjoner. Når det er sagt, er det viktig å påpeke at bruken av ANT er her ment som en tilncerming som bidrar til å rette oppmerksomhet og fokus mot noen valgte områder, ikke som et forsøk på å skape en helhetlig teori om sosiale normer for deling.

Et annet nyttig perspektiv innen ANT er at det fremmer en empirinær tilnærming hvor konkrete og observerbare hendelser holdes i fokus. Fokus rettes dermed mot selve prosessene, det vil si mot relasjonene og forbindelsene mellom aktører når de utspiller seg. På denne måten tilbyr ANT en tilnærming ulik sosiologiske studier som fokuserer på sosiale strukturer eller samfunnet som bakenforliggende forklaringer for menneskers handlinger og handlingsrom. Latour var kritisk til å bruke samfunnet og det sosiale som forklaring, da han mente det var å bruke det sosiale (eks. struktur, makt, normer) for å forklare det sosiale (eks. menneskers adferd) (Sørenssen, 2014).

Når det innen ANT påpekes at det ikke-menneskelige bør ses som aktør med mulighet for agentskap, betyr ikke det at det materielle har intensjon eller vilje lik mennesker, men fremhever en symmetrisk relasjon hvor verken menneskelige eller ikke-menneskelige aktører gis forrang som subjekt. Agens og agentskap kan sies å bli brukt noe ulikt i ANT enn andre retninger, da det viser til at en bred forståelse av aktør som noe eller noen som gjør noe i møte med de andre aktørene. Det vil si noe som utgjør en forskjell og utløser en respons eller handling. Innen ANT anses ikkemenneskelige aktører som å ha agens i form av at de muliggjør, oppmuntrer, tillater, foreslår, lokker, begrenser og hindrer handling i møte med andre aktører. ANT tilbyr slik en annerledes tilnærming til forholdet mellom ikke-menneskelige entiteter og mennesker ved at det materielle ses som aktive deltakere istedenfor å se «...materialene som en del av konteksten eller som artefakter i forlengelsen av menneskelige intensjoner og handlinger» (Lafton, 2016b, s. 19). Det er viktig å presisere at det ikke er snakk om å lete etter enkle årsak-virkningsforhold, da aktørene ikke anses som 


\section{Karianne Franck}

årsaker, men som mediatorer som utløser noe hos de andre aktørene. Fokuset er på hvordan aktører utløser eller trigger noe hos de andre aktørene, uten at man på forhånd kan vite hva eller hvordan. På den måten åpnes det for at uforutsette ting kan utspille seg. Hva en aktør (menneskelig og/eller ikke-menneskelig) gjør med de andre aktørene og hvilken forskjell den har i en situasjon, er med andre ord ikke gitt i forkant (Latour, 2005).

Det er gjort en god del forskning med ulike perspektiv og teoretisk forankring vedrørende barn og materialitet i barnehagen, spesielt med fokus på gjenstander, interiør og rommets betydning (f.eks. Gilliam \& Gulløv, 2012; Løkken, 2004; Seland, 2011). Det kan også sies å være en økende interesse for bruk av ANT som tilnærming til barn, rom og materialitet i barnehagefeltet. I sin avhandling bruker Tove Lafton ANT som tilnærming når hun utforsker konstruksjoner av barnehagepraksiser i møte med teknologi (2016b). Hun har også brukt ANT for å re-tenke barnehagens ledelsespraksiser (2016a). Solveig Nordtømme (2015) utforsker barns lekerfaringer i samspill med rom og materialitet ved å bruke begrep fra aktør-nettverksteori sammen med Merleau-Ponty sin kroppsfenomenologi. Og Dag Øystein Nome (2017) har gjort en ANT-analyse av lek i småbarnsavdelinger. Denne artikkelen kan dermed leses som et bidrag inn $i$ et gryende forskningsfelt som tar i bruk ANT for å belyse hendelser og praksiser i barnehagen.

\section{Metodisk tilnaerming}

Artikkelen er basert på data fra feltarbeid gjennomført høsten 2009 og våren $2011 \mathrm{i}$ forbindelse med mitt doktorgradsarbeid ${ }^{1}$. Feltarbeidet bestod av deltagende observasjon i 4 barnehageavdelinger (to småbarns- og to storbarnsavdelinger) og semistrukturerte intervju med 16 ansatte ved de samme avdelingene. Metodisk utforming av studiet var godkjent av NSD, og alle etiske retningslinjer er fulgt. De ansatte ga informert skriftlig samtykke, og alle foreldre ble informert om forskningsprosjektet. Alle navn og andre identifiserbare opplysninger er i denne teksten fjernet eller anonymisert. For mer inngående redegjørelse av intervju og metode, se Franck (2014). Empirien fremstilt $\mathrm{i}$ artikkelen er ikke tidligere omtalt $\mathrm{i}$ avhandlingen og består hovedsakelig av observasjoner fra feltarbeidet. I det følgende vil jeg utdype gjennomføringen av deltagende observasjon samt bruk av ANT som tilnærming til datamaterialet.

Den deltagende observasjonen hadde et omfang på ca. 3 måneder (omlag tre uker i hver avdeling). Hensikten med observasjonene var å få innblikk i kompleksiteten og konteksten for praksis og å skrive ned «tykke beskrivelser» (jfr. Geertz, 1993) i form av detaljerte og utdypende feltnotater. Under feltarbeidet skrev jeg korte notat og kommentarer vedrørende daglige hendelser og uformelle samtaler med de ansatte, mens mer utfyllende beskrivelser ble skrevet på et senere tidspunkt samme dag. I en

${ }^{1}$ Resultert i avhandlingen: Constructions of children in-between normality and deviance in Norwegian day-care centres. (Franck, 2014) 
egen del noterte jeg også min forståelse og undringer angående det som oppstod i felten. Til tross for forsøk på å skrive så detaljert som mulig, vil feltnotater alltid være basert på mine fortolkninger og kun representere et utvalg, da det ikke er mulig å skrive ned alt (jfr. Hammersley \& Atkinson, 2007). Men som Geertz påpeker: «it is not necessary to know everything in order to understand something» (1993, s. 20).

Min rolle i felten varierte avhengig av avdelingen og barnehagehverdagens ulike situasjoner. For det meste var jeg mer observerende enn deltagende (jfr. Hammersley og Atkinson, 2007), og jeg satt gjerne på gulvet eller i en stol nær de ansatte og barnegruppa uten nødvendigvis å delta aktivt i de ansattes gjøremål. Når jeg så det var en åpning til å delta eller de ansatte uttrykte et ønske om min deltagelse, bidro jeg $\mathrm{i}$ form av å rydde, dekke på mat, holde barn i hånda på tur og lignende. Min interaksjon med barna på avdelingene varierte avhengig av barnas egne initiativ. Jeg imøtekom barns initiativ og befant meg ofte i aktivitet med barna. Feltarbeidet ga meg en bedre forståelse og innsikt $i$ både barnas og barnehagens hverdagsliv, noe som var meget betydningsfullt da jeg kan sies å inneha en posisjon som "outsider» $\mathrm{i}$ barnehagen, ettersom jeg ikke har bakgrunn som førskolelærer eller ansatt i barnehagen. Dermed ble det viktig for meg å være i felten og opparbeide meg en nærhet til barnehagens hverdag, mens det ble mindre problematisk for meg å inneha en nødvendig distanse for refleksjon og kunne legge merke til det som tas for gitt. Det er som kjent både fordeler og utfordringer om man har posisjon som «insider» eller en «outsider» $i$ felten (Corbin Dwyer \& Buckle, 2009).

Analyse og tolkning av datamaterialet begynte allerede under feltarbeidet og fortsatte til skrivende stund. Analysen er resultatet av en kontinuerlig refleksjonsprosess (jfr. Alvesson \& Sköldberg, 2009). Valg av fokus for denne artikkelen har vært styrt av det som var utfordrende for meg å forstå, det som fanget min oppmerksomhet under feltarbeidet og førte mitt blikk videre. I drøftingsdelen fremstilles ulike hverdagslige situasjoner i barnehagen i lys av hverandre for å fremheve kompleksiteten og utfordre tatt for gitte forståelser av sosiale normer for deling. Jeg trekker fram likheter og ulikheter i hverdagslige hendelser for å belyse det jeg anser for å være motsigelser, skiftninger og brytninger i praksis. Ved bruk av ANT tar analysene utgangspunkt i det som er tilgjengelig i de konkrete situasjonene, både det som sies og giøres, men også kropp og materialitet (jfr. Lafton, 2016a). På mange måter kan ANT sies å utgjøre mer en analytisk tilnærming enn en teori, men ANT er ikke ment som en verktøykasse eller form for oppskrift for analyse. Ved å bruke ANT forsøker man i stedet å tilnærme seg et felt med en annerledes sensitivitet (Bauer, 2015). I analyser tar jeg som sagt utgangspunkt i det materielle som aktør, hvorpå jeg retter blikket mot hvordan lekgjenstander i samspill med barnas kropper bidrar til hvordan sosiale normer utspiller seg i situasjonene. Når barnehageansatte for eksempel ber et barn om å dele leker, analyseres denne handlingen i sammenheng med andre aktører som er tilstede i situasjonen. Den sosiale normen om deling utforskes dermed ved å belyse forbindelsene mellom aktørene tilstede, heller enn å fokusere ensidig på den ansatte. Påfølgende omtaler jeg sosiale normer ved at de finner steg eller utspiller seg, uten å forklare normen ut fra en enkelt person. 


\section{Karianne Franck}

De barnehageansatte som deltok i studien hadde ulik bakgrunn og stilling, alt fra pedagogiske ledere, spesialpedagoger og assistenter. Jeg har valgt å benevne dem som barnehageansatte, fordi deres bakgrunn og stilling ikke er del av analysen. Det er heller ikke min intensjon å foreta noen form for vurdering av de ansattes praksis eller kompetanse.

I en enkelt hendelse kan det være veldig mange aktører som former flere nettverk. I artikkelen har jeg valgt å ha fokus først og fremst på det materielle, ettersom ideen om å sidestille det ikke-menneskelige og menneskelige muligens er ANT sin mest radikale oppfordring (Bauer, 2015). Målet er å utforske: Hvordan utspiller sosiale normer for deling seg i barnehagen, og hvordan bidrar det materielle som aktør? Det som presenteres i analyse og drøfting er ment å leses som en blant flere måter å reflektere over hendelsene og fenomenet deling på.

\section{"Å dele sammen» eller "Førstemann sin rett»}

I denne delen vil jeg skissere to situasjoner jeg observerte i en småbarnsavdeling. Eksemplene viser hverdagslige hendelser som begge omhandler to barn, en lekgjenstand, en barnehageansatt og en sosial norm om deling. I etterkant vil jeg undersøke hendelsene nærmere med fokus på det materielle og belyse hvordan noenlunde like situasjoner mellom barn kan føre til ulike sosiale normer for deling.

\section{Dukkehuset}

I en småbarnsavdeling, mellom stoler, bord, leker og voksnes fang og føtter, stabber, går og kravler barn i ett til tre års alder. De undersøker nysgjerrig former og fasonger. Er det plass til hele kroppen min inne i lekekomfyren? Så myk og deilig sofaen er, kanskje vi kan skli ned fra den? Mange lyder blandes i rommet. De ansatte sitter på gulv og puffer, tilgjengelige for barnas initiativ og lek, og veiledende når samhandling bryter sammen og lyden i rommet preges av gråt og frustrasjon. Jeg sitter sammen med de ansatte på gulvet og skifter fokus mellom å snakke med dem og respondere nysgjerrige barn. På bordet mot veggen og i høyden til barna står det et rosa dukkehus. Det har to etasjer og er brettet ut så man kan se innsiden. Jeg observerer situasjoner der flere barn ønsker å leke med dukkehuset samtidig. Det er gjerne ett barn som er først ute, og så kommer et annet nysgjerrig barn bort til huset. Flere ganger observerte jeg at barna uttrykte det jeg tolket som misnøye i å være fler om samme dukkehus. I slike situasjoner brøt gjerne en av de ansatte inn og ba barna om å dele dukkehuset. Her er en kort beskrivelse av en slik situasjon, der jeg observerte Ida og Ole som begge var ca. 2,5 år:

Ida står og titter inn i dukkehuset. Hun holder det med begge hender og trykker på ringeklokken og det kommer en lyd. Ole kommer bort til bordet, tar på huset og gjør tegn til å ville leke med det. Ida forsøker da å trekke huset nærmere seg selv og dermed vekk fra Ole. En ansatt griper inn og sier til barna at de må dele og begge kan se inn i huset. Huset blir plassert tilbake til midten av bordet. 
I det videre forløpet brøt Ida ut i gråt og lagde lyder i verbal protest. Ole fortsatte leken med huset mens en ansatt gikk bort til Ida og snakket med henne i noe som så ut som forsøk på å roe henne og forklare henne at hun og Ole måtte dele dukkehuset. Litt senere fortalte den ansatte meg at Ida ikke var så flink til å dele. Jeg vil påstå at denne situasjonen gjenspeiler ganske vanlige hendelser i barnehagen, inkludert den ansatte sin beskjed om at barn må dele. Stående for seg selv vil jeg dermed ikke hevde at situasjonen med dukkehuset er særlig oppsiktsvekkende. Den er til og med et eksempel som kan brukes for å bekrefte den ansattes påstand om at Ida ikke var så flink til å dele. Det som gjør situasjonen mer interessant, er når den sees opp imot barns lek med dukkevognen.

\section{Dukkevognen}

Inne på småbarnsavdelingen var det akkurat nok rom til å gå med en liten dukkevogn rundt spisebordet. Det virket som det var stor stas for barna å gå rundt med vognen og putte saker og ting nedi dukkevognen. Det var ikke nødvendigvis en dukke som lå der, men alt ifra legoklosser, vesker, puter og annet barna kunne finne. En formiddag er det Martin som holder $\mathrm{i}$ vognen da Johan kommer bort og tar tak i håndtaket til vognen. En av de ansatte ser situasjonen og retter seg mot Johan og sier: «Det var Martin som hadde vognen først». Videre ber den ansatte Johan finne på noe annet og vente til Martin er ferdig med vognen.

En sosial norm om deling utspiller seg i det den ansatte sier at det barnet som har leken først har rett til å ikke dele leken med det andre barnet. Jeg har valgt å kalle det førstemann-sin-rett. Denne retten illustreres i eksemplet da Johan tar tak i dukkevognens håndtak, og den ansatte responderer med å forklare Johan at Martin hadde dukkevognen først og at han må vente til Martin er ferdig. Med andre ord så får Martin fortsette å leke med vognen alene. Førstemann-sin-rett kan sees som en slags «eiendomsrett» berettiget til det barnet som har lekegjenstanden først. En rett som opphørte (slik jeg forstod reglene) når et barn fysisk slapp leken og gikk vekk eller begynte å leke med noe annet. En sosial norm om førstemann-sin-rett ble bekreftet $\mathrm{i}$ intervju med barnehageansatte, og kan nok hevdes å være en sosial norm som ofte utspiller seg i barnehager. Normen ble spesielt synlig i tilfeller der barn tok leker fra andre barn. For eksempel i uteleken observerte jeg daglig at ansatte påpekte at barn ikke fikk lov til å ta spaden eller bøtta som et annet barn lekte med. Noe som også forklarer hvorfor mange barn ba meg og andre ansatte passe på leker for dem når de måtte på do eller lignende.

Ved første øyekast er det også lite oppsiktsvekkende at en norm om førstemannsin-rett finner sted i situasjonen beskrevet ovenfor. Det kan sies å være noe som tas for gitt som del av hverdagslig praksis. For en utenforstående som meg var det dog uklart hvorfor den sosiale normen om førstemann-sin-rett utspilte seg i situasjonen med dukkevognen, til forskjell fra normen om å dele leken sammen som kom til syne i situasjonen med dukkehuset. Jeg begynte å lure; hvorfor får ikke Martin beskjed om å dele dukkevognen med Johan? Eller, hvorfor får ikke Ole beskjed om at Ida hadde 


\section{Karianne Franck}

dukkehuset først og må vente til hun er ferdig? Å besvare de spørsmålene er ikke min hensikt her, men ved å nærme seg de sosiale normene som forbindelser mellom ulike aktører ønsker jeg å fremheve det materielle sitt bidrag inn i hvordan normene utspiller seg og blir til i konkrete situasjoner.

Noe av likheten i de situasjonene skissert ovenfor kan sies å være at to barn uttrykker ønske om å leke med samme gjenstand på samme tid, hvorpå en barnehageansatt går i dialog med barna (og gjenstanden) og en sosial norm om deling utspiller seg. For å kaste nytt lys over disse hverdagslige hendelsene og de sosiale normene har jeg valgt å utforske det som skjer i de to situasjonene med fokus på det materielle som aktør og forbindelsene mellom de menneskelige og ikke-menneskelige aktørene.

\section{Dukkehuset og dukkevognen som aktører}

Situasjonene beskrevet ovenfor omhandler (blant annet) ulike materielle leker, nærmere bestemt et dukkehus og en dukkevogn. Forståelser av sosiale normer kan sies sjeldent å ta i betraktning det materielle som aktive deltagere i det sosiale samspillet. Materielle gjenstander behandles gjerne som passive element som tillegges sosial verdi, hvorpå de menneskelige subjekt anses primært som aktivt handlende. Som en alternativ tilnærming vil jeg derfor fremheve nettopp det materielle sin aktørskap, ved å undersøke hvordan dukkehuset og dukkevognen kan sees som bidragsytere når ulike sosiale normer om deling finner sted. Det er ikke ment som forsøk på å finne årsaker med kausal effekt, men å se på de ulike forbindelsene som skjer mellom aktørene i møtet.

La meg først beskrive dukkehuset i forbindelse med barna: Dukkehuset er fysisk stort, relativt til barnas fysiske størrelse, og det er noenlunde stabilt ved at det er tungt for yngre barn å flytte dukkehuset i sin helhet. Dukkehuset i relasjon til barna kan sies å oppfordre til aktivitet uten særlig grad av forflytning i rommet. Dukkehusets fysiske størrelse i form av å være bredt, muliggiør at to mindre barn står side om side og leker med huset. En slik relasjonell beskrivelse av dukkehusets materialitet i forbindelse med barnas kropper kan sees opp mot en sosial norm om å dele, ved at dukkehusets materialitet muliggjør et handlingsrom for deling. Dukkehusets utforming som et hus, med rom, møbler, dører, vinduer og muligens figurer, kan også hevdes å gi assosiasjoner til rollelek. Rollelek innebærer ofte samhandling mellom flere barn og er blant barnehageansatte en ønsket og anerkjent form for lek. Dukkehusets utforming, sammen med ansattes positive fokus på rollelek, kan også ha innvirkning på den sosiale normen om deling i situasjonen. I samhandlingen beskrevet ovenfor mellom Ida, Ole, dukkehuset og en barnehageansatt vil dukkehusets materialitet her forstås som en ikke-menneskelig aktør ved at den gjør noe med (utløser respons hos) de andre aktørene (jfr. Latour, 2005). Dukkehusets materialitet som relativt stort og stabilt, og en utforming som minner om rollelek, kan sies å være delaktig i at en sosial norm om at barna skal leke med gjenstanden sammen finner sted. Det kan være viktig å påpeke at med dette menes det ikke at dukkehuset determinerer hva som utspiller seg i situasjonen. I møte med de andre aktørene kan man som sagt ikke forutsi hva slags sosiale 
normer som produseres (Latour, 2005). Lekens materialitet skal med andre ord leses som ett aspekt (blant flere) som bidrar inn i det sosiale samspillet i form av at det vil utgjøre en forskjell hvis dukkehuset blir byttet ut med en annen gjenstand.

Materialitetens bidrag blir tydeligere når man sammenligner eksemplet med dukkehuset opp mot en lignende hendelse med en annen ikke-menneskelig aktør, nærmere bestemt dukkevognen. Dukkevognen kan på én side også sies å gi assosiasjoner til rollelek, men mine observasjoner viste at dukkevognen i liten grad ble brukt til rollelek, og i større grad ble brukt til å frakte ulike ting og bevege seg i rommet. Dukkevognen er lik dukkehuset stor av størrelse i forhold til barnas fysiske kropper, og den gir rom for flere barn å stå ved siden av den. På en annen side kan dukkevognen sies å muliggiøre, oppfordre og lokke til bevegelse i rommet og forflytning ved at den har hjul og er stødig nok til at små barn kan støtte seg til den og er dermed enkel for yngre barn å forflytte. For yngre barn som relativt nylig har lært å gå, kan det å kunne støtte seg til en dukkevogn også tillate og oppmuntre til større fart enn når de beveger seg rundt i rommet på egen hånd. Som påpekt av Nome (2017) vil aktørene $i$ et nettverk kunne endre hverandres handlingsrom og bevegelighet (s. 10). På den måten kan man si at dukkevognen fungerer som aktør som muliggiør og endrer barnas bevegelser i rommet. For to yngre barn å bevege seg rundt i et mindre rom mens de styrer retning og støtter seg til samme dukkevogn kan man derimot se for seg at vil være utfordrende. Relasjonen mellom barn og dukkevogn giør dermed noe med den ansatte som aktør og bidrar til at en norm om førstemann-sin-rett utspiller seg. Førstemann-sin-rett som sosial norm om deling kan med andre ord ses i lys av forbindelser som utspiller seg mellom de ulike aktørene, hvorav dukkevognen (det materielle) aktivt gjør noe med de andre aktørene i den konkrete hendelsen (jfr. Latour, 2005). Ved å se situasjonene om dukkehuset og dukkevognen i lys av hverandre settes videre fokus på hvordan ulike materielle gjenstander kan gjøre en forskjell for hvilke sosiale normer som utspiller seg i barnehagen.

I beskrivelsene av dukkevognen og dukkehuset som aktører har jeg vektlagt å beskrive lekene (de ikke-menneskelige, materielle aktørene) i forbindelse med barnas kropper. For eksempel ved at dukkehuset kan beskrives som stort og tungt i forbindelse med toåringers kroppslige styrke. På denne måten settes fokus både på de ulike enhetene (her: dukkehuset, dukkevognen, barnas kropp) og det relasjonelle (møtet mellom dukkehus-barns kropp, og dukkevognen-barns kropp) uten at det ene eller det andre gis forrang (jfr. McFarlane \& Anderson, 2011). Det er også mulig å se til andre hverdagslige situasjoner for å illustrere dette poenget. Som nevnt var det i uteleken til stadighet møter mellom barn, spader, bøtter og de ansatte, hvorpå en sosial norm om førstemann-sin-rett fant sted. Ved å se spadene som sosiale aktører som gjør noe aktivt med situasjonen, blir det vesentlig å påpeke utformingen av deres materialitet i møte med barns kropp, for eksempel barns hender. Spadene er små i fysisk størrelse, de har håndtak som oppfordrer til å holde fast, men gir kun plass til én hånd og begrenser mulighetene for to barn fysisk å holde fast i en spade samtidig. Spadenes materialitet begrenser med andre ord antall barn i å leke med spaden samtidig, noe som kan bidra til at førstemann-sin-rett som sosial norm utspiller seg. 


\section{Karianne Franck}

Tidligere forskning av Torgeir Alvestad (2012) påpeker at barns forhandlinger kan være forskjellige på bakgrunn av store og små lekgjenstander, ved at små gjenstander gjør det vanskelig for barn å ta den andres perspektiv. Ensidig fokusering på størrelsen til lekgjenstanden vil etter min mening derimot være en forenkling som risikerer å overse andre aspekt ved det materielle i møte med barna. Dukkevognen, som er stor sett i lys av de yngste barnas kropper, vil som nevnt likevel kunne begrense muligheter for deling. Og man kan se for seg hvordan en liten ball kan oppfordre til deling ved bevegelse (f.eks. trille frem og tilbake) mellom barna. Ved å undersøke nærmere flere aspekt ved de ikke-menneskelige aktørenes materialitet i samhandling med de andre aktørene vil et mer nyansert bilde kunne fremtre.

I første del av analysen har jeg rettet særskilt fokus mot det materielle sitt bidrag når sosiale normer utspiller seg i konkrete, hverdagslige situasjoner. De ansatte i barnehagen fremhevet derimot i intervju barnas intensjoner som sentrale for hvilke normer om deling som utspiller seg. Jeg vil kort beskrive hva de ansatte fortalte både for å nyansere artikkelens fokus på det materielle, men også for å påpeke hvordan deres forståelse ikke nødvendigvis er en motsetning til en tilnærming som inkluderer det materielle.

\section{Å forstå ungens ønske og intensjon}

De ansatte ble spurt i intervju hva de legger til grunn når de vurderer om det er deling eller førstemann-sin-rett som skal gjøres gjeldende. Et par barnehageansatte forklarte da at de la vekt på det de mente var ønskene og intensjonene til de ulike barna som var involvert i de konkrete hendelsene. De ga inntrykk av å kjenne barna svært godt, og kunne på bakgrunn av dette avgjøre hvilke sosiale normer som var viktige å fremheve i en gitt situasjon. Ett av aspektene som dukket opp, var at de ansatte sa de tolket intensjonen eller ønsket til barnet som gikk bort til en leke et annet barn hadde først. For eksempel kunne man se det slik at Ole ikke forsøkte å ta dukkehuset vekk fra Ida, og derfor ba den ansatte Ida om å dele dukkehuset - i motsetning til Johan som kunne tolkes som å forsøke å ta dukkevognen fra Martin, og derfor fikk beskjed om at Martin hadde den først. Hvilken norm som fant sted, kunne dermed anses som påvirket av ansattes forståelse av intensjonene og ønskene til de barna som var deltagende i situasjonen.

For det er så forskjell på når ... søker ungen samspill - (Å ja.) Eller når vil han på en måte ... - ha leken for egen lek - (OK.) Ja. Så du må på en måte lese litt ungen sitt ønske. (Sitat barnehageansatt).

I sitatet forklarer en ansatt sin vurdering av hvorvidt hen vil si til et barn at de må dele på noe sammen eller påpeke førstemann-sin-rett til å beholde leken for seg selv. Med god kjennskap til de enkelte barna og barnegruppen kan man si at de ansatte hadde mulighet til å «lese ungen sitt ønske». I noen sammenhenger vil slike ønsker være svært tydelige, mens i andre situasjoner er det trolig subtile tegn som uttrykkes av barna og tolkes av de ansatte. Det kan være utallige detaljer og nyanser 
som ligger til grunn for ansattes forståelse og praksis knyttet til slike hverdagslige situasjoner. Slike vurderinger kan sies å være del av de ansattes profesjonelle skjønn (jfr. Åmot, 2014) og kan forstås som en forbindelse mellom de ansatte og barna som bidrar til at ulike sosiale normer utspiller seg. I den sammenheng har jeg ingen intensjon om å betvile de ansattes vurderinger. Det er ikke min hensikt å vurdere hvorvidt det var riktig eller galt å be Ida dele dukkehuset eller la Martin ha førstemann-sin-rett på dukkevognen.

Jeg vil derimot påpeke at det er mulig å åpne for at ansattes vurdering av barnas intensioner bidrar til at sosiale normer for deling finner sted uten at dette utelukker det materielle sitt bidrag som aktører i situasjonene. Barnas intensjoner, eller ansattes tolkninger av disse, vil jo også kunne sies å være preget av lekens materialitet. Dukkehusets bidrag $\mathrm{i}$ å skape et handlingsrom for deling kan sies å giøre noe med Oles intensjon da han nærmer seg Ida og dukkehuset, på samme tid som dukkehusets utforming kan sies å giøre noe med ansattes forståelse av hva Ole sin intensjon er. Med andre ord vil relasjonene og forbindelsene mellom både de ansatte, barna og det materielle kunne sies å bidra til å forme den sosiale normen om deling som utspiller seg. På samme tid vil jeg påpeke at ettersom de ansattes tolkning av barns intensjoner risikerer å skifte avhengig av profesjonelt skjønn, materiale og situasjon, fordrer dette til videre refleksjon omkring hva et barn må kunne for å handle i tråd med normer og regler som finner sted i ulike situasjoner.

Det kan også være relevant å påpeke at i en travel barnehagehverdag vil det være flere tilfeller der de ansatte ikke har hatt mulighet til å observere situasjonene før det oppstår uenighet mellom barna vedrørende lekgjenstander. I de situasjonene vil ikke de ansatte ha grunnlag for å tolke hva barnas intensjoner og ønsker var i forkant av konflikten, og ansattes forforståelse av noen barn som flinke eller ikke flinke til å dele vil også kunne utgjøre en forskjell for hvilken sosial norm som utspiller seg.

\section{Situasjonsbestemte normer om deling}

Så langt har artikkelen utforsket situasjoner i barnehagen der normer om deling (inklusive ikke å dele: første-mann-sin-rett) utspiller seg når de blir brutt. I denne delen vil jeg rette oppmerksomheten mot settinger hvor sosiale normer for deling er klart uttalt i forkant og knyttet til bestemte situasjoner. De situasjonsbestemte normene for deling i barnehagen kan ved første øyekast ses som en sosial orden. Innen ANT vil man derimot hevde at det ikke finnes noen sosial orden, men heller uendelige forsøk på å skape orden (Law sitert i Müller, 2015).

En setting som hadde klarlagt normene for deling, var turtaking av syklene i uteområdet. Turtaking vil jeg beskrive som en form for deling der barna må bytte på hvem som får ha en leke, hvorpå et barn kan bli nødt til å gi fra seg leker som hen holder på med, muligens før hen egentlig ønsker det. I den ene barnehagen jeg observerte, bidro de ansatte til å opprettholde en norm om turtaking av trehjulssykler i uteleken ved at de til en viss grad regulerte når et barn skulle gi fra seg en sykkel og når et barn måtte vente på tur. Utfra mine observasjoner vil jeg hevde at det var mange variabler 


\section{Karianne Franck}

som spilte inn for å avgjøre når et barn skulle gi fra seg en sykkel, og når et barn måtte vente på tur. Til tider virket det noenlunde tilfeldig, basert blant annet på ansattes inntrykk av hvor lenge et barn hadde hatt en sykkel. Jeg vil ikke gå videre inn i en analyse av trehjulssyklene, men påpeke hvordan en overordnet idé om turtaking som situasjonsbestemt norm ikke nødvendigvis er tilfredsstillende for å forstå hvordan turtaking utspiller seg i konkrete hendelser mellom barn, ansatte og sykler.

Andre situasjoner med faste normer for deling utspilte seg blant annet ved matbordet. Her observerte jeg hvordan fruktfat med oppkuttet frukt ble sendt rundt bordet i lunsjtiden for å lære barna å dele mellom seg. Jeg observerte også hvordan det ved samme matbordet til frokosten utspilte seg en norm om at barna ikke skulle dele mat, da de satt med hver sin matboks medbragt hjemmefra. Det å ikke å dele fra matboksen ble ofte ignorert av barna - med et stort smil om munnen. Med andre ord: samme barn, samme bord, samme ansatt, men ulik mat og ulikt tidspunkt på dagen. I den sammenheng ble jeg forklart av de ansatte at restene i matboksene utgjorde en form for informasjon til foreldrene vedrørende hvor mye deres barn hadde spist til frokost. Med andre ord fungerte maten i matboksene som aktører innvevd i flere nettverk, både med barna og ansatte under frokosten, og med barnas foreldre.

De situasjonsbestemte normene i barnehagen skapte en ny undring hos meg som forsker. På en side kunne de anses for å være forholdvis enkle å forstå, men på en annen side kunne brudd forstås på flere vis...: alt fra barns manglende forståelse for sosiale normer om deling, men også at barn forsøker å iverksette sosiale normer som finner sted i andre situasjoner i barnehagen. Med andre ord kan man på én side hevde at barn som ikke vil dele under fruktmåltidet innehar manglende kompetanse $i$ å dele, mens et alternativt perspektiv vil kunne si at barnet forsøker å få en sosial norm om ikke å dele mat til å utspille seg - noe som faktisk finner sted i måltidet med matbokser. Så hvordan vil man vurdere og forstå Ida (som i eksemplet med dukkehuset ble karakterisert som ikke flink til å dele) når hun med et lurt smil gir sidemannen en brødbit fra matboksen sin under frokosten? Får hun anerkjennelse for at hun deler, eller blir Ida nok en gang ansett for å bryte de sosiale normene?

\section{Avsluttende tanker}

I en myriade av hverdagslige hendelser utspiller ulike sosiale normer seg, frembrakt av forbindelser mellom ulike menneskelige og ikke-menneskelige aktører. Min intensjon med å illustrere en håndfull av disse situasjonene må ikke leses som et forsøk på å overkomme variasjonen eller skape statiske regler, men nettopp å påpeke hvordan ulike aktører, både menneskelige og ikke-menneskelige, bidrar når sosiale normer utspiller seg. Som utenforstående lette jeg i utgangspunktet etter overgripende mønstre eller strukturer som kunne hjelpe meg å navigere i barnehagens terreng. Resultatet har derimot blitt det motsatte, ved å fremheve paradoksene og utfordringene i og mellom konkrete hendelser i barnehagens hverdagsliv.

Med utgangspunkt i aktør-nettverksteori (ANT) bruker jeg en tilnærming som inkluderer det ikke-materielle som aktør, og argumenterer for en utforskning av konkrete hendelser for å forstå hvordan sosiale normer utspiller seg i barnehagens hverdagsliv. 
Ved å fokusere på forbindelsene mellom menneskelige og ikke-menneskelige aktører, har intensjonen til denne artikkelen vært å komme med en alternativ tilnærming som kan føre til nye tanker og refleksjoner.

Ulike tilnærminger kan sies å gi ulike forståelser av det som skjer i hverdagen, noe som har reelle konsekvenser i praksis. En tilnærming som vurderer barns kompetanse i å dele kunne ha brukt empirien i artikkelen som eksempler på enkeltbarns manglende evne i å dele, og endt med fokus på barns manglende empati (f.eks. Svetlova, Nichols, \& Brownell, 2010) eller manglende evne til å ta den andres perspektiv (f.eks. Alvestad, 2012). En slik individfokusert tilnærming vil videre kunne ha konsekvenser for praksis ved at noen barn behandles annerledes samt potensielt medvirke til at barn karakteriseres som å ha spesialpedagogiske behov (Franck, 2014). Ansatte i barnehagen blir jevnlig bedt om å komme med generelle beskrivelser av enkeltbarn. Som Nordin-Hultman (2004) påpeker, så ender man da ofte med å finne noe "typisk» eller hvordan barnet «egentlig» er. Slike beskrivelser underslår opplysninger fra de konkrete hendelsene.

En alternativ tilnærming som aktør-nettverksteori (ANT) kan forstyrre slike beskrivelser av enkeltbarn ved at de sosiale normene forstås som del av flytende og skiftende forbindelser som skapes og endres i samspillet mellom ulike aktører. Ved å rette blikket mot ulike aktører og nettverkene de inngår i fremmes en annen forståelse og syn på enkeltbarn og deres handlinger, hvorpå verken enkeltbarn eller sosiale normer kan vurderes og forstås uavhengig av aktørnettverkene de inngår i. I denne artikkelen har fokus hovedsakelig vært på det materielle og hvordan ulike lekgjenstander i forbindelse med barns kropper bidrar når ulike sosiale normer for deling utspiller seg. Målet har både vært å introdusere en sensitivitet for det materielle sitt bidrag, samt å fremheve kompleksiteten og paradoksene som oppstår når sosiale normer for deling finner sted i en barnehagehverdag. Undringer om hvilke sosiale normer og regler som gjøres gjeldende og forståelsen av barn som bryter reglene, ble drevet frem på bakgrunn av at jeg, til tross for min livserfaring med både å dele og hevde min rett, var like tilbøyelig til å ta «feil» som selv de yngste barna.

\section{Biografi}

Karianne Franck er ansatt som førsteamanuensis i pedagogikk ved Dronning Mauds Minne Høgskole. Franck er utdannet sosialantropolog og har en PhD i Tverrfaglig Barneforskning ved Norsk Senter for Barneforskning (NOSEB) ved NTNU. Franck har tidligere publisert i nasjonale og internasjonale tidsskrift og bidratt med kapitler i fagbøker for barnehagelærerutdanning og masterstudiet i spesialpedagogikk.

\section{Litteraturliste}

Alvesson, M., \& Sköldberg, K. (2009). Reflexive methodology: new vistas for qualitative research (Second edition ed.). London: Sage.

Alvestad, T. (2012). Små barns forhandlinger i lek. Oslo: Cappelen Damm Akademisk.

Bauer, I. (2015). Approaching geographies of education differently. Children's Geographies, 13(5), 620-627.

Brownell, C. A., Svetlova, M., \& Nichols, S. (2009). To share or not to share: When do toddlers respond to another's needs? Infancy, 14(1), 117-130. 


\section{Karianne Franck}

Corbin Dwyer, S., \& Buckle, J. L. (2009). The space between: On being an insider-outsider in qualitative research. International fournal of Qualitative Methods, 8(1), 54-63.

Dolwick, J. S. (2009). The social'and beyond: Introducing actor-network theory. fournal of Maritime Archaeology 4(1), 21-49.

Franck, K. (2014). Constructions of children in-between normality and deviance in Norwegian day-care centres. PhDavhandling ved Norges teknisk-naturvitenskapelige universitet, Trondheim.

Geertz, C. (1993). The Interpretation of Cultures: Selected Essays. London: Fontana.

Gilliam, L., \& Gulløv, E. (2012). Civiliserende Institutioner: Om idealer og distinktioner i opdragelse. Aarhus: Aarhus universitetsforlag.

Hammersley, M., \& Atkinson, P. (2007). Ethnography: principles in practice. London: Routledge.

Harris, M. B. (1970). Reciprocity and generosity: Some determinants of sharing in children. Child Development, 41(2), 313-328.

Krarup, T. M., \& A. Blok (2011). Unfolding the social: quasi-actants, virtual theory, and the new empiricism of Bruno Latour. The Sociological Review 59(1), 42-63.

Lafton, T. (2016a). Nye blikk på distribuert ledelse. I T. Krüger, P. E. Leirhaug, D. Wilson, \& L. T. Grindheim (Red.), Larerprofesjonalitet $i$ utdanningspraksiser, (s. 41-58). Bergen: Fagbokforlaget.

Lafton, T. (2016b). Refleksjoner og handlinger $i$ barnehagens møter med teknologi. Sosio-materielle teorier som optikk for (re) konstruksjoner av barnehagepraksiser. PhD-avhandling ved Universitetet i Oslo, Oslo.

Latour, B. (2005). Reassembling the social: An introduction to actor-network-theory. United Kingdom: Oxford university press.

Law, J. (2009). Actor network theory and material semiotics. I B. S. Turner (Red.) The new Blackwell companion to Social Theory, (s.141-158). Wiley \& Blackwell. Lastet ned fra: https://is.muni.cz/el/1423/jaro2012/ SOC403/um/Turner_New_Blackwell_Companion_to_Social_Theory.pdf\#page=156

Løkken, G. (2004). Toddlerkultur: Om ett- og toåringers sosiale omgang $i$ barnehagen. Oslo: Cappelen Damm Akademisk.

McFarlane, C., \& Anderson, B. (2011). Thinking with assemblage. Area, 43(2), 162-164.

Müller, M. (2015). Assemblages and actor-networks: Rethinking socio-material power, politics and space. Geography Compass, 9(1), 27-41.

Nome, D. Ø. (2017). De yngste barna og tingene deres - en ANT-analyse av lek i småbarnsavdelinger. Tidsskrift for Nordisk barnehageforskning, 14(6), 1-17.

Nordin-Hultman, E., Solli, A., \& Jansen,T.T. (2004). Pedagogiske miljøer og barns subjektskaping. Oslo: Pedagogisk forum.

Nordtømme, S. (2015). En teoretisk utdyping av rom og materialitet som pedagogisk ressurs i barnehagen. Tidsskrift for Nordisk Barnehageforskning, 10(4), 1-14.

Seland, M. (2011). Livet $i$ den fleksible barnehagen: muligheter og utfordringer $i$ en barnehage $i$ endring. Oslo: Universitetsforlaget.

Svetlova, M., Nichols, S. R., \& Brownell, C. A. (2010). Toddlers' prosocial behavior: From instrumental to empathic to altruistic helping. Child Development, 81(6), 1814-1827.

Sørenssen, I. K. (2014). Domesticating the Disney Tween Machine: Norwegian Tweens Enacting Age and Everyday Life. PhD-avhandling ved Norges teknisk-naturvitenskapelige universitet, Trondheim.

Åmot, I. (2014). Barn med samspillsvansker og ansattes dilemma relatert til retten til medvirkning $i$ barnehagen. PhDavhandling ved Norges teknisk-naturvitenskapelige universitet, Trondheim. 